\title{
ОЦІНКА БУГАЇВ-ПЛІДНИКІВ ЗА ЕКСТЕР'ЄРНИМ ТИПОМ ТА ЯКІСНИМ СКЛАДОМ МОЛОКА ЇХ ДОЧОК
}

\author{
Адміна Наталія Григорівна \\ кандидат сільськогосподарських наук, старший науковий співробітник \\ Інститут тваринництва НААН \\ ORCID: 0000-0001-5224-2640 \\ E-mail: natalyadm5@gmail.com \\ Осипенко Тетяна Леонідівна \\ кандидат сільськогосподарських наук, старший науковий співробітник \\ Інститут тваринництва НААН \\ ORCID: 0000-0002-2605-3587 \\ E-mail: tanyaos7109@gmail.com \\ Філіпенко Ірина Дмитрівна \\ аспірант \\ Інститут тваринництва НААН \\ ORCID: 0000-0002-2605-3555 \\ E-mail: irinaworld2017@gmail.com
}

Адмін Олександр Євгенович кандидат сільськогосподарських наук, старший науковий співробітник ТОВ ТБ Українські ветеринарні технології E-mail: aeadmin@rambler.ru

В статті оцінено бугаїв-плідників за екстер'єрним типом та якісним складом молока їх дочок. Проведені дослідження дозволили дифреренціювати бугаїв-плідників за екстер'єрним типом будови тіла та вим'я їхніх дочок. За результатами дисперсійного аналізу вплив бугая-плідника на комплекс екстер'єрних ознак, які характеризують вираженість молочного типу корови склав 18,2 \%, тулуба - 10,5 \%, стан кінцівок/ратиць - 17,3 \%, стан морфоологічних ознак вим'я 16,2 \% (P>0,95). За ознаками екстер'єру, які характеризують молочний тип корів спостерігалась достовірна мінливість з коливаннями оцінки від 80,1 до 82,9 балів, тулуба - від 80,6 до 82,7 балів. Від бажаного розвитку ознак кінцівок значним чином залежить тривалість господарського використання тварин в сучасних умовах промислової технології утримання. Сама низька оцінка за комплекс ознак кінцівок виявилась у дочок бугая Бессона 393035302 (79,8 бали), а найвища у потомків Чапман 0347903595 - 81,7 бали. Варіативність оцінок за ознаки вим'я становила від 78,7 балів (дочки Ельдорадо 579136891) до 82,3 балів (дочки бугая Чапмана 0347903595) з різницею між цими крайніми варіантами 3,6 балів. Серед бугаїв-плідників української чорно-рябої молочної породи, які використовувалися у ДП ДГ „Гонтарівка”, з найкращим балом за екстер'єрний тип (83,0 балів) виявлено бугая Чапмана 0347903595, дочки якого характеризувалися бажаним розвитком статей будови тіла і вим'я $(P>0,95)$. За допомогою дисперсійного аналізу було визначено ступінь впливу бугаївплідників на надій та якісний склад молока їхніх дочок та, зокрема, вміст соматичних клітин. Найбільший добовий надій було отримано від дочок бугая-плідника Ельдорадо 579136891, що на 2,2 ке молока більше ніж від дочок Доміно 1500162599. Найкращий вміст жиру та білку у молоці виявлено у дочок бугая-плідника Бессона 393035302, але й вміст соматичних клітин у них також найвищий, що може свідчити про наявність субклінічного маститу. Сила впливу бугаївплідників невисока, хоча присутня генетична схильність тварини до підвищеного вмісту соматичних клітин.

Ключові слова: українська чорно-ряба молочна порода, лінійна класифікація типу будови тіла, бугаї-плідники, корова, соматичні клітини.

DOI: https://doi.org/10.32845/bsnau.lvst.2019.1-2.6

Визначення племінної цінності плідників за екстер'єрним типом дочок і інтенсивне використання лідерів $\epsilon$ основним засобом селекційного поліпшення худоби за будьяких методів розведення [1, 2], оскільки відомо, що понад 90 \% ефректу селекції забезпечується використанням кращих племінних бугаїв. [3]. Тому оцінка бугаїв-плідників за екстер'єрним типом та якісним складом молока їх дочок $є$ актуальним завданням.

Результати досліджень свідчать про наявність переважно додатного і достовірного кореляційного зв'язку лінійної оцінки молочних корів за типом будови тіла з продуктивним довголіттям, молочною продуктивністю, із числом сома- тичних клітин у молоці. За повідомленням Perez Cabal M.A. [4] генетична кореляція між прибутком і ознаками будови тіла становить від 0,12 для вигляду кінцівок збоку до 0,37 для центральної зв'язки вимені. Schneider M.P.B. et al. [5] та Swelem A.B. [6] зі співавторами, що корови з низькою оцінкою вимені мали найбільший процент вибраковки. За даними Rogers G.W.B. et al. [7] кількість соматичних клітин у молоці зростає при слабкому прикріпленні передньої частини вимені (150-190), глибині вимені нижче скакального суглоба (200-250), при низькій висоті прикріплення задньої частини вимені (100-150), при невираженій центральній зв'язці вимені (100-150), а також, коли корова має короткі

Вісник Сумського національного аграрного університету 
дійки (150-180). Результати численних досліджень різних авторів свідчать про високі коефіцієнти успадковуваності різних ознак лінійної оцінки корів за типом. При оцінці бугаївплідників за якістю дочок обов'язковою умовою $є$ щомісячне визначення кількості соматичних клітин у молоці корів як об'єктивний показник здоров'я вим'я тварин, який входить до складу загального селекційного індексу в США, Канаді, країнах Європи. Хоча успадковуваність цього показника не надто висока і становить за різними джерелами 10-40\% [8, 9], але вкрай важлива.

Мета наших досліджень полягала у визначенні племінної цінності бугаїв-плідників за екстер'єрним типом їх дочок та якісним складом молока.

Матеріали та методи досліджень. Дослідження виконували в стаді племінного заводу із розведення української чорно-рябої молочної породи ДП ДГ „Гонтарівка” Харківської області протягом 2019 року. В господарстві використовують бугаїв-плідників, перевірених за якістю нащадків закордонної селекції, згідно з розробленим науковою установою перспективним планом селекційно-племінної роботи. Лінійну класифікацію типу корів-первісток проводили на 2-4 місяці лактації за двома системами: лінійний опис окремих 18 ознак екстер'єру та оцінка комплексних ознак типу за 100бальною шкалою [10]. Оцінку корів за молочною продуктивністю проводили за матеріалами племінного обліку (форма
№ 2-мол, форма № 4-мол). Вміст соматичних клітин у молоці визначали у лабораторії Інституту тваринництва НААН на обладнанні форми Bentley. Опрацювання експериментальних даних проводили за основними статистичними методами (кореляційний та дисперсійний аналізи).

Результати досліджень. Для того, щоб об'єктивно оцінити селекційну ситуацію у стаді та визначити заходи щодо добору тварин на перспективу, необхідно провести оцінку бугаїв-плідників за якістю потомства в конкретних умовах їхнього використання. Якщо не враховувати при підборі вплив бугаїв на тип будови тіла їхніх дочок, це може викликати послаблення конституції корів і відповідно зменшити тривалість використання останніх у стадах. Тому правильний підбір бугая-плідника для подальшого відтворення стада є досить важливим та відповідальним заходом.

Результати оцінки бугаїв-плідників за типом їхніх дочок в умовах ДП ДГ „Гонтарівка” наведено у таблиці 1.

Доведено вірогідний вплив бугаїв-плідників на екстер'єрні ознаки їх дочок. Генетично обумовленим є ріст корів ( $\left.\eta_{\mathrm{x}}^{2}=25,3 \%\right)$, кутастість $\left(\eta_{\mathrm{x}}^{2}=17,2 \%\right)$ та заднє прикріплення вим'я $\left(\eta_{\mathrm{x}}^{2}=17,3 \%\right), \quad \mathrm{P}>0,95 ;$ глибина вим'я $\left(\eta_{\mathrm{x}}^{2}=17,8 \%\right)$, розміщення передніх дійок $\left(\eta_{\mathrm{x}}^{2}=18,0 \%\right)$, $\mathrm{P}>0,99$ та центральна зв'язка вим'я ( $\left.\eta_{\mathrm{x}}^{2}=10,0 \%\right), \mathrm{P}>0,999$.

Оцінка бугаїв-плідників за типом їхніх дочок в умовах ДП ДГ „Гонтарівка”, балів

Таблиця 1

\begin{tabular}{|c|c|c|c|c|c|c|c|c|c|c|c|c|c|c|c|c|c|c|}
\hline \multirow[b]{3}{*}{$\begin{array}{c}\text { Бугаї- } \\
\text { плідники }\end{array}$} & \multirow[b]{3}{*}{ 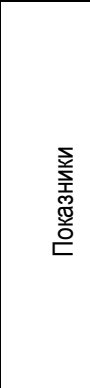 } & \multicolumn{17}{|c|}{ Описові ознаки } \\
\hline & & \multicolumn{6}{|c|}{ Тулуб } & \multicolumn{3}{|c|}{ Кінцівки } & \multicolumn{4}{|c|}{ Вим'я } & \multicolumn{3}{|c|}{ Дійки } & \multirow[b]{2}{*}{ 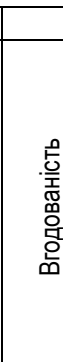 } \\
\hline & & .' & 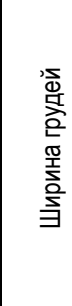 & 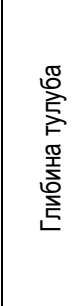 & 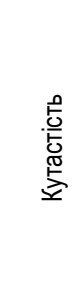 & 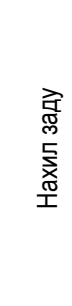 & 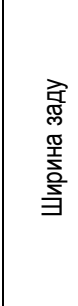 & 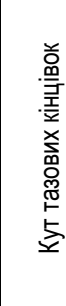 & 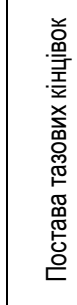 & 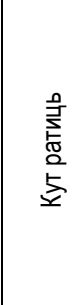 & 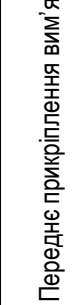 & 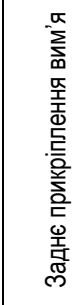 & 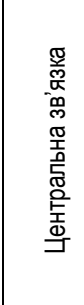 & 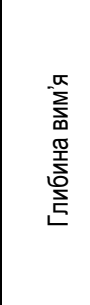 & 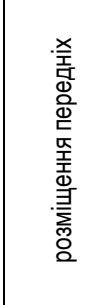 & 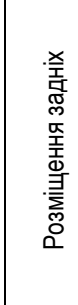 & $\begin{array}{l}\text { 㸒 } \\
\text { 畨 } \\
\text { 品 }\end{array}$ & \\
\hline \multirow{3}{*}{$\begin{array}{l}\text { БессоH } \\
393035302\end{array}$} & $n$ & 11 & 11 & 11 & 11 & 11 & 11 & 11 & 11 & 11 & 11 & 11 & 11 & 11 & 11 & 11 & 11 & 11 \\
\hline & $M$ & 5,9 & 7,0 & 6,6 & 6,3 & 6,7 & 6,1 & 4,6 & 4,8 & 3,8 & 5,5 & 4,5 & 5,2 & 5,5 & 7,8 & 5,8 & 4,4 & 5,2 \\
\hline & $\pm m$ & 0,33 & 0,27 & 0,43 & 0,24 & 0,20 & 0,33 & 0,21 & 0,24 & 0,23 & 0,64 & 0,34 & 0,57 & 0,41 & 0,31 & 0,40 & 0,24 & 0,26 \\
\hline \multirow{3}{*}{$\begin{array}{l}\text { Доміно } \\
1500162599\end{array}$} & $n$ & 21 & 21 & 21 & 21 & 21 & 21 & 21 & 21 & 21 & 21 & 21 & 21 & 21 & 21 & 21 & 21 & 21 \\
\hline & $M$ & 6,3 & 5,3 & 5,3 & 6,4 & 5,5 & 7,2 & 7,3 & 5,5 & 5,6 & 5,6 & 6,4 & 5,5 & 7,1 & 4,6 & 6,3 & 4,5 & 4,8 \\
\hline & $\pm m$ & 0,18 & 0,14 & 0,21 & 0,20 & 0,18 & 0,14 & 0,29 & 0,34 & 0,18 & 0,42 & 0,29 & 0,41 & 0,14 & 0,23 & 0,26 & 0,13 & 0,20 \\
\hline \multirow{3}{*}{$\begin{array}{l}\text { Ельдорадо } \\
579136891\end{array}$} & $\mathrm{n}$ & 51 & 51 & 51 & 51 & 51 & 51 & 51 & 51 & 51 & 51 & 51 & 51 & 51 & 51 & 51 & 51 & 51 \\
\hline & $\mathrm{M}$ & 6,4 & 6,8 & 5,8 & 6,4 & 6,4 & 6,6 & 5,4 & 6,0 & 4,1 & 5,3 & 6,1 & 5,8 & 7,8 & 5,0 & 5,5 & 4,2 & 5,4 \\
\hline & $\pm m$ & 0,13 & 0,13 & 0,15 & 0,11 & 0,12 & 0,11 & 0,14 & 0,15 & 0,14 & 0,27 & 0,17 & 0,28 & 0,14 & 0,13 & 0,20 & 0,11 & 0,15 \\
\hline \multirow{3}{*}{$\begin{array}{l}\text { Чапман } \\
0347903595\end{array}$} & $n$ & 49 & 49 & 49 & 49 & 49 & 49 & 49 & 49 & 49 & 49 & 49 & 49 & 49 & 49 & 49 & 49 & 49 \\
\hline & $M$ & 6,9 & 6,2 & 5,8 & 8,0 & 5,1 & 6,7 & 5,7 & 5,1 & 3,9 & 4,7 & 5,3 & 6,1 & 5,6 & 5,5 & 4,8 & 4,5 & 5,1 \\
\hline & $\pm m$ & 0,12 & 0,14 & 0,16 & 0,13 & 0,12 & 0,11 & 0,14 & 0,20 & 0,11 & 0,28 & 0,19 & 0,30 & 0,11 & 0,14 & 0,16 & 0,09 & 0,13 \\
\hline \multirow{3}{*}{$\begin{array}{l}\text { В } \\
\text { середньому }\end{array}$} & $n$ & 132 & 132 & 132 & 132 & 132 & 132 & 132 & 132 & 132 & 132 & 132 & 132 & 132 & 132 & 132 & 132 & 132 \\
\hline & $M$ & 6,4 & 5,8 & 5,4 & 6,8 & 4,9 & 5,6 & 5,7 & 5,1 & 4,5 & 5,3 & 5,0 & 5,4 & 6,3 & 6,0 & 6,6 & 4,4 & 5,1 \\
\hline & $\pm m$ & 0,08 & 0,08 & 0,10 & 0,08 & 0,07 & 0,07 & 0,09 & 0,11 & 0,07 & 0,17 & 0,11 & 0,18 & 0,08 & 0,09 & 0,11 & 0,06 & 0,09 \\
\hline $\begin{array}{l}\text { Сила } \\
\text { впливу }\end{array}$ & $\eta_{\mathrm{x}}^{2}, \%$ & $25,3^{*}$ & 3,25 & 3,44 & $17,2^{*}$ & 4,14 & 4,45 & 0,72 & 1,15 & 1,26 & 2,94 & $17,2^{*}$ & $10^{* * *}$ & $17,7^{\star *}$ & $18,0^{* *}$ & 1,6 & 2,83 & 3,87 \\
\hline
\end{tabular}

Нашими дослідженнями встановлено, що найбільш високорослими були дочки бугая Чапмана (6,9 балів) та Ельдорадо 579136891 (6,4 бали). Вони переважали за показниками росту на 0,1-1,0 бали корів-первісток, народжених від інших бугаїв-плідників. Оцінка кутастості свідчить про те, що дочки всіх бугаїв мали високу вираженість цієї ознаки (у межах 6,3-8 балів). Найкраще молочний тип був виражений у дочок Чапмана 0347903595, які мали оцінку кутастості на 1,7 балів вищу, ніж у Бессона 393035302.

Показники оцінки ширини та глибини тулуба, які характеризують розвиток травного тракту тварини, знаходились у середніх межах від 5,3 до 7,0 балів. Середні значення 
мали й показники оцінки нахилу заду корів (5,1-5,5 балів) за виключенням дочок бугаїв-плідників Бессона 393035302 (6,7 балів) та Ельдорадо 579136891 (6,4 балів), що мали дещо опущений зад.

Найбільшою шириною заду характеризувалися дочки Доміно 1500162599 (оцінка у 7,2 бали), що на 1,1 бали вище у порівнянні з дочками Бессона 393035302.

За результатами оцінки бажаний розвиток згину кута скакального суглоба встановлено у дочок бугаїв Чапмана 0347903595 та Ельдорадо 579136891 (5,4 - 5,7 балів). Дочки бугая Бессона 393035302 мали оцінку за кут тазових кінцівок 4,6 балів що свідчить про пряму поставу їхніх кінцівок, а у дочок бугая Доміно 1500162599 спостерігалась помірна шаблистість 3 оцінкою у 7,3 бали. Усі корови-первістки піддослідного стада, незалежно від походження за батьком, відрізнялися доброю поставою задніх кінцівок та достатньою оцінкою за стан кута ратиць (4,8- 6,0 балів).

Краще прикріплення передніх часток вим'я виявлено у дочок бугая Доміно 1500162599 (5,6 балів), які за рівнем оцінки статі незначно перевищують решту груп дочок на 0,1 0,9 балів. Найкраще прикріплення задніх часток вим'я виявилося також у дочок Доміно 1500162599 (6,4 балів), а найгірше - у дочок Бессона 393035302 (4,5 балів) з достовірною різницею між ними 1,9 балів ( $p \geq 0,999)$. Незначна мінливість оцінки за розвиток центральної зв'язки у межах 5,2-6,1 бали свідчить про певну вирівняність тварин за цією ознакою та про її незначну слабкість. Що стосується глибини, розміщення дійок та їхньої довжини, які характеризують технологічність тварин, то встановлено, що дочки всіх буга- їв-плідників характеризувалися глибиною вим'я, вищою за її середній розвиток $(5,57,8)$, що задовольняє технологічні вимоги машинного доїння. У процесі оцінювання виявлено, що всі первістки піддослідного стада мали короткі дійки 3 оцінкою в межах 4,2-4,5 балів, а також - їх заднє зближення.

Оцінку бугаїв-плідників за комплексом екстер'єрних ознак їхніх дочок в умовах ДП ДГ „Гонтарівка” наведено у таблиці 2.

За результатами дисперсійного аналізу вплив бугаяплідника на комплекс екстер'єрних ознак, які характеризують вираженість молочного типу корови склав 18,2 \%, тулуба - 10,5 \%, стан кінцівок/ратиць - 17,3 \%, стан морфологічних ознак вим'я - 16,2\% (P>0,95).

Проведені нами дослідження дозволили достатньою мірою диференціювати бугаїв-плідників за екстер'єрним типом будови тіла та вим'я їхніх дочок.

За ознаками екстер'єру, які характеризують рівень вираженості молочного типу корів спостерігалась достовірна мінливість 3 коливаннями оцінки від 80,1 до 82,9 балів, тулуба - від 80,6 до 82,7 балів. Від бажаного розвитку ознак кінцівок значним чином залежить тривалість господарського використання тварин в сучасних умовах промислової технології утримання. Сама низька оцінка за комплекс ознак кінцівок виявилась у дочок бугая Бессона 393035302 (79,8 бали), а найвища - у потомків Чапман 0347903595 - 81,7 бали. Варіативність оцінок за ознаки вим'я становила від 78,7 балів (дочки Ельдорадо 579136891) до 82,3 балів (дочки бугая Чапмана 0347903595) з різницею між цими крайніми варіантами 3,6 балів.

Таблиия 2

Оцінка бугаїв-плідників за комплексом екстер'єрних ознак оцінки їхніх дочок за типом в умовах ДП ДГ „Гонтарівка”, балів

\begin{tabular}{|c|c|c|c|c|c|c|}
\hline \multirow{2}{*}{ Бугаї-плідники } & \multirow{2}{*}{ Показники } & \multicolumn{5}{|c|}{ Комплекси екстер'єрних ознак } \\
\hline & & молочний тип & тулуб & кінцівки & вим'я & загальна оцінка \\
\hline \multirow{2}{*}{ Бессон 393035302} & $\mathrm{n}$ & 11 & 11 & 11 & 11 & 3 \\
\hline & $\mathrm{M} \pm \mathrm{m}$ & $81,8 \pm 1,09$ & $82,0 \pm 0,87$ & $79,8 \pm 3,88$ & $81,4 \pm 3,99$ & $81,2 \pm 1,09$ \\
\hline \multirow{2}{*}{ Доміно 1500162599} & $\mathrm{n}$ & 21 & 21 & 21 & 21 & 4 \\
\hline & $\mathrm{M} \pm \mathrm{m}$ & $82,6 \pm 0,88$ & $81,7 \pm 0,61$ & $80,1 \pm 0,79$ & $79,9 \pm 1,60$ & $80,7 \pm 0,41$ \\
\hline \multirow{2}{*}{ Ельдорадо Тв Тл DE 579136891} & $\mathrm{n}$ & 51 & 51 & 51 & 51 & 10 \\
\hline & $\mathrm{M} \pm \mathrm{m}$ & $80,1 \pm 0,62$ & $80,6 \pm 0,81$ & $79,8 \pm 0,55$ & $78,7 \pm 1,87$ & $80,2 \pm 1,81$ \\
\hline \multirow{2}{*}{ Чапман DE 0347903595} & $\mathrm{n}$ & 49 & 49 & 49 & 49 & 12 \\
\hline & $\mathrm{M} \pm \mathrm{m}$ & $82,9 \pm 0,71$ & $82,7 \pm 0,84$ & $81,7 \pm 0,78$ & $82,3 \pm 2,06$ & $83,0 \pm 0,99$ \\
\hline \multirow{2}{*}{ В середньому } & $\mathrm{n}$ & 132 & 132 & 132 & 132 & 29 \\
\hline & $\mathrm{M} \pm \mathrm{m}$ & $81,9 \pm 0,46$ & $81,8 \pm 0,44$ & $80,9 \pm 0,41$ & $80,6 \pm 1,15$ & $81,3 \pm 0,76$ \\
\hline Сила впливу & $\eta_{\mathrm{x}}^{2} \%$ & 18,2 & 10,5 & 17,3 & 16,2 & 16,6 \\
\hline Вірогідність & $P<$ & $0,011^{*}$ & $0,045^{*}$ & $0,021^{*}$ & $0,042^{*}$ & $0,629^{*}$ \\
\hline
\end{tabular}

Серед бугаїв-плідників української чорно-рябої молочної породи, які використовувалися у ДП ДГ „Гонтарівка”, з найкращим балом за екстер'єрний тип (83,0 бали) виявлено бугая Чапмана DE 0347903595, дочки якого характеризувалися бажаним розвитком статей будови тіла і вим'я $(P>0,95)$.

Загальновідомо, що одним із показників здоров'я вим'я корів вважається вміст соматичних клітин у молоці. За допомогою дисперсійного аналізу нами визначено ступінь впливу бугаїв-плідників на надій та якісний склад молока їхніх дочок та, зокрема, вміст соматичних клітин (табл. 3).

Як видно із таблиці 3, найбільший добовий надій було отримано від дочок бугая-плідника Ельдорадо
579136891, що на 2,2 кг молока більше ніж від дочок Доміно 1500162599. Найкращий вміст жиру та білку у молоці виявлено у дочок бугая-плідника Бессона 393035302, але й вміст соматичних клітин у них також найвищий, що може свідчити про наявність субклінічного маститу. Сила впливу бугаївплідників - невисока, хоча присутня генетична схильність тварини до підвищеного вмісту соматичних клітин. Існують й інші фрактори, що впливають на їхню кількість у молоці. Це механічні пошкодження вим'я, запалення, не пов'язані 3 вим'ям, фізіологічний стан тварини, її продуктивність, технологічні недоліки і недбалість операторів машинного доїння, неякісні корми та інші. 


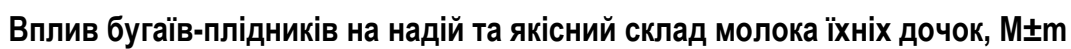

\begin{tabular}{|l|c|c|c|c|c|}
\hline \multicolumn{1}{|c|}{ Бугай-плідник } & $\mathrm{n}$ & Добовий надій, кг & Вміст жиру, \% & Вміст білку, \% & Вміст соматичних клітин тис./см ${ }^{3}$ \\
\hline Бессон 393035302 & 9 & $20,5 \pm 1,41$ & $3,91 \pm 0,102$ & $3,27 \pm 0,098$ & $694 \pm 142,0$ \\
\hline Доміно 1500162599 & 17 & $19,5 \pm 0,83$ & $3,45 \pm 0,065$ & $2,71 \pm 0,039$ & $210 \pm 59,7$ \\
\hline Ельдорадо 579136891 & 44 & $21,7 \pm 0,51$ & $3,63 \pm 0,049$ & $3,14 \pm 0,028$ & $320 \pm 56,2$ \\
\hline Чапман 0347903595 & 43 & $19,8 \pm 0,37$ & $3,82 \pm 0,045$ & $2,88 \pm 0,038$ & $223 \pm 54,3$ \\
\hline Сила впливу & & $18,6^{*}$ & $6,7^{* *}$ & $4,4^{* * *}$ & $4^{*}$ \\
\hline
\end{tabular}

Висновки. 1. Доведено вірогідний вплив бугаївплідників на екстер'єрні ознаки їх дочок. Генетично обумовленим $є$ ріст корів ( $\left.\eta_{\mathrm{x}}^{2}=25,3 \%\right)$, кутастість ( $\eta_{\mathrm{x}}^{2}=17,2$ \%) та заднє прикріплення вим'я $\left(\eta_{\mathrm{x}}^{2}=17,3 \%\right), \quad \mathrm{P}>0,95$; глибина вим'я ( $\left.\eta_{\mathrm{x}}^{2}=17,8 \%\right)$, розміщення передніх дійок $\left(\eta_{\mathrm{x}}^{2}=18,0 \%\right), \mathrm{P}>0,99$ та центральна зв'язка вим'я $\left(\eta_{\mathrm{x}}^{2}=10,0\right.$ $\%), P>0,999$.

2. За результатами дисперсійного аналізу вплив бугая-плідника на комплекс екстер'єрних ознак, які характеризують вираженість молочного типу корови склав

18,2 \%, тулуба - 10,5 \%, стан кінцівок/ратиць - 17,3\%, стан морфологічних ознак вим'я - 16,2 \% $(\mathrm{P}>0,95)$. За результатами дисперсійного аналізу вплив бугая-плідника на комплекс екстер'єрних ознак, які характеризують вираженість молочного типу корови склав 18,2 \%, тулуба $10,5 \%$, стан кінцівок/ратиць - 17,3\%, стан морфологічних ознак вим'я - 16,2 \% (P>0,95).

3. Сила впливу бугаїв-плідників на вміст соматичних клітин у молоці невисока $(4,1 \%)$, хоча присутня генетична схильність тварин до їх підвищеного вмісту.

\section{Список використаної літератури:}

1. Полупан Ю. П. Оцінка бугаїв за типом дочок. Вісник аграрної науки. 2000. № 5. С. 45-49.

2. Хмельничий Л. М. Метод визначення племінної цінності бугаїв-плідників за екстер'єрним типом дочок. Вісник аграрної науки. 2007. № 1. С. 40-43.

3. Полупан Ю. П., Йовенко И. В., Гавриленко Н. С., Коваль Т. П. Генеалогическая структура и племенная ценность быков красного молочного скота - Descrierea CIP a Camerei Nationale a Cărtii „Realizări si perspective in cresterea animalelor” Materialele simpozionului ştiinţific consarcrat jubileului de 50 de ani de la fondarea Institutului de Zootehnie şi Medicină Veterinară. Maximovea. 2006. C. 163-166.

4. Perez Cabal M. A., Alenda R. Genetic Relationships between Lifetime Profit and Type Traits in Spanish Holstein Cows $J$ Dairy Sci. 2002. Vol. 85, Iss. 12. P. 3480-3491. DOI: 10.3168/jds.S0022-0302(02)74437-8.

5. Schneider M. P., Dürr J. W., Cue R. I., Monardes H. G. Impact of Type Traits on Functional Herd Life of Quebec Holsteins Assessed by Survival Analysis J Dairy Sci. 2003. Vol. 86, Iss. 12. P. 4083-4089. DOl.org/10.3168/jds.S0022-0302(03)74021-1.

6. Swalem A. B., Kistemaker G.J.B., Miglior F.B. Analysis of the Relationship Between Type Traits and Functional Survival in Canadian Holsteins Using a Weibull Proportional Hazards Model J Dairy Sci. 2004. Vol. 87, Iss. 11. P. 3938-3946. DOI:10.3168/jds.s0022-0302(04)73533-x.

7. Rogers G. W .B., Hargrove G.L.B., Cooper J. B. B. Correlations Among Somatic Cell Scores of Milk Within and Across Lactations and Linear Type Traits of Jerseys J Dairy Sci. 1995. Vol. 78, Iss. 4. P. 914-920. DOI:10.3168/jds.S0022-0302(95)767066.

8. Reents R., Jamrozik J., Schaeffer L. R., Dekkers J. C. M. Estimation of Genetic Parameters for Test Day Records of Somatic Cell Score J. Dairy Sci. 1995. Vol. 78. P. 2847-2857. DOI:10.3168/jds.S0022-0302(95)76915-6

9. Shook G. E., Schutz M. M. Selection on Somatic Cell Score to Improve Resistance to Mastitis in the United States. J. Dairy Sci. 1994. Vol 77. P. 648-658. DOI:10.3168/jds.S0022-0302(94)76995-2

10. Хмельничий Л. М., Ладика В. І., Полупан Ю. П., Салогуб А. М. Методика лінійної класифікації корів молочних і молочно-м'ясних порід за типом. Суми: ВВП “Мрія-1” ТОВ, 2008. 28 с.

\section{References:}

1. Polupan Yu. P., 2000. Otsinka buhaiv za typom dochok [Evaluation of boogie by type of daughters]. Visnyk ahrarnoi nauky. issue 5, pp. 45-49.

2. Khmelnychyi L. M., 2007. Metod vyznachennia pleminnoi tsinnosti buhaiv-plidnykiv za ekster'iernym typom dochok. [A method for determining the breeding value of a booger-breeder by the exterior type of daughters.]. Visnyk ahrarnoi nauky. issue 1 , pp. 40-43.

3. Polupan Yu. P., Yovenko Y. V., Havrylenko N. S., Koval T. P., 2006. Henealohycheskaia struktura y plemennaia tsennost bukov krasnoho molochnoho skota [Genealogical structure and breeding value of red dairy cattle]. Descrierea CIP a Camerei Nationale a Cărtii „Realizări si perspective in cresterea animalelor” - Materialele simpozionului ştiinţific consarcrat jubileului de 50 de ani de la fondarea Institutului de Zootehnie şi Medicină Veterinară. - Maximovea, pp. 163-166.

4. Perez Cabal M. A., Alenda R., 2002. Genetic Relationships between Lifetime Profit and Type Traits in Spanish Holstein Cows J Dairy Sci. Vol. 85, issue 12, pp. 3480-3491. DOI: 10.3168/jds.S0022-0302(02)74437-8.

5. Schneider M. P., Dürr J. W., Cue R. I., Monardes H. G., 2003. Impact of Type Traits on Functional Herd Life of Quebec Holsteins Assessed by Survival Analysis $\underline{J}$ Dairy Sci. 2003. Vol. 86, issue 12. pp. 4083-4089. DOl.org/10.3168/jds.S00220302(03)74021-1.

6. Swalem A. B., Kistemaker G.J.B., Miglior F.B., 2004. Analysis of the Relationship Between Type Traits and Functional 
Survival in Canadian Holsteins Using a Weibull Proportional Hazards Model J Dairy Sci. 2004. Vol. 87, issue 11. pp. 3938-3946. DOI:10.3168/jds.s0022-0302(04)73533-x.

7. Rogers G. W .B., Hargrove G.L.B., Cooper J. B. B., 1995 Correlations Among Somatic Cell Scores of Milk Within and Across Lactations and Linear Type Traits of Jerseys J Dairy Sci. Vol. 78, issue 4. pp. 914-920. D0I:10.3168/jds.S00220302(95)76706-6.

8. Reents R., Jamrozik J., Schaeffer L. R., Dekkers J. C. M., 1995. Estimation of Genetic Parameters for Test Day Records of Somatic Cell Score J. Dairy Sci. 1995. Vol. 78. pp. 2847-2857. DOI:10.3168/jds.S0022-0302(95)76915-6

9. Shook G. E., Schutz M. M., 1994. Selection on Somatic Cell Score to Improve Resistance to Mastitis in the United States. J. Dairy Sci. Vol 77. pp. 648-658. DOI:10.3168/jds.S0022-0302(94)76995-2

10. Khmelnychyi L. M., Ladyka V. I., Polupan Yu. P., Salohub A. M., 2008. Metodyka liniinoi klasyfikatsii koriv molochnykh i molochno-m'iasnykh porid za typom [Method of linear classification of cows of dairy and dairy breeds by type]. Sumy : Mriia, pp. 28.

Admina, N. G.,

Osipenko, T. L.,

Filipenko, I. D.,

Admin, O.E.

Evaluation sires of line type score and milk quality of their daughters

The article estimates of Sires of Line Type Score and Milk quality of their Daughters. The studies have made it possible to differentiate of Line Type Score and the Udder of their Daughters. According to the results of the variance analysis, the effect of the Sires on the Dairy Strength of the cow was 18,2 \%, the Frame - 10,5\%, the condition of the Feet and Legs - 17,3\% (P>0,95), the Mammary - $16,2 \%$ ( $P>0.95)$. On the exterior features that characterize the Dairy Strength, significant variability was observed with fluctuations from 80.1 to 82.9 points, Frame - from 80,6 to 82,7 points. The economic use of animals in modern industrial technology of stable nursing depends largely on the desirable development of the features of the Feet and Legs. The lowest score for a complex of the Feet and Legs was in daughters of the Besson 393035302 (79,8 points), and the highest in the descendants of Chapman 0347903595 - 81,3 points. The variability of the Mammary ranged from 78,7 points (Eldorado's daughter 579136891) to 82,3 points (Chapman's daughter 0347903595), with a difference of 3,6 points. Among the descendants of Ukrainian Black-and-White dairy breed used in "Gontarivka", Chapman's Sire 0347903595 was found with the best Line Type Score (83,0 points), whose daughters were characterized by desirable development of Body Type and Udder $(P>0,95)$. The degree of influence of the sires on the milk yield and quality composition of milk of their daughters and, in particular, the content of somatic cells was determined by means of analysis of variance. The highest daily milk yield was obtained from daughters of the sire Eldorado 579136891 , which is $2,2 \mathrm{~kg}$ of milk more than the daughters of Domino 1500162599. The best fat and protein content in milk was found in daughters of the sire Besson 393035302, but also the content of somatic cells in them also the highest that can indicate the presence of subclinical mastitis. The power of the bulls is low, although there is a genetic predisposition of the animal to the heightened content of somatic cells.

Key words: Ukrainian Black-and-White dairy breed, line type score, sires, cows, somatic cells.

Дата надходження до редакції: 11.03.2019 p. 